\title{
Nexus Between Tax Havens and Illicit Financial Flow of Funds(IFFs) from Africa: A Theoretical Review
}

\author{
Ishola Rufus AKINTOYE \\ Professor of Accounting \& Strategic Financial Management, \\ Department of Accounting, School of Management Sciences, Babcock University Ilishan-Remo, Nigeria \\ Olateju Abiola SOMORIN \\ Professor of Taxation \& Fiscal Policy, College of Postgraduate Studies, Caleb University Lagos, Nigeria \\ Ayodeji Temitope AJIBADE \\ Department of Accounting, School of Management Sciences, Babcock University Ilishan-Remo, Nigeria \\ Olubunmi Adewole OGUNODE* \\ Department of Accounting, School of Management Sciences, Babcock University Ilishan-Remo, Nigeria
}

\begin{abstract}
This paper examined the nexus between tax havens and illicit financial flow of funds with particular reference to capital flows out of the African continent. Qualitative content analysis method supported with empirical data obtained from multilateral agencies was used for the study. The dataset covered forty-four (44) African countries for the period 2005-2014 respectively. Results revealed that the absence of political will, weak institutional framework, poor regulatory oversight and the unbridled scramble for the continent's mineral resources are some of the key factors responsible for the continued rise in IFFs from Africa. The study also found that the absence of global consensus on the proper treatment of tax havens remains a challenge to fostering the needed international collaboration to fight the scourge. It therefore recommended that critical stakeholders like the press and civil society groups in their roles as public watchdogs need to do more to track and report incidences of IFFs timeously. Also, on the international front, efforts must be made to ensure that the proposed new minimum, global corporate tax rate of $15 \%$ is adhered to as a needed first step to discourage funds flow to tax havens.
\end{abstract}

Keywords: Tax Havens, Illicit financial flow of funds, Tax Evasion, Africa, Economic Development

JEL Classification: B22, E63, H26

DOI: $10.7176 /$ RJFA/13-2-06

Publication date: January $31^{\text {st }} 2022$

\section{INTRODUCTION}

The subjects of tax havens and illicit financial flow of funds (IFFs) are twin issues that have gained increased prominence in recent times particularly because of their overall impact on the global economy. It has been argued that the volume and value of illicit financial flow of funds originating from developing countries and terminating in tax havens and other developed nations cannot be adequately assessed especially because of the poor record keeping practice of most African countries (Herkenbath 2015).Also, a number of studies have shown that Africa is lagging behind the rest of the world due largely to its inability to hold on to capital flows in the continent (Ortega, Sanjuan and Casquero 2020, Igbatayo 2020, Ndikumana 2013, Kar and Cartwright-Smith 2010).

Different scholars have attempted the valuation of funds lost using various measurement methodologies with varying results. Gumede and Fadiran (2018) estimated that IFFs from the Southern Africa region alone within a fifteen years period (2000 to 2015) amounted to \$11.27 trillion. The Global Financial Integrity report of 2015 puts its estimate for the same period at $\$ 10.6$ trillion. These were largely due to leakages in the balance of payments of nation states, deliberate under-reporting, under-invoicing and similar other schemes. Others have posited that over a 38-year period, the sum total of funds illegally moved out of Africa is in the region of $\$ 1.3$ trillion (Signe, Sow and Madden 2020). Irrespective of the differences in valuation, scholars generally agree that the sums leaving the shores of the continent if retained would have been significant enough to make a difference to poverty levels and other socio-economic challenge bedeviling African countries (Mugarura 2017, Forstater 2018, Onanuga 2018).

Tax havens on the other hand harbor a disproportionate percentage of the world's sum total of foreign direct investment (Dharmapala 2008). About 25\% of all UK and USA's foreign direct investment (FDI) is hosted in tax havens, even though they are home to less than $0.8 \%$ of the world's total population (Dharmapala and Hines 2006). They feature prominently in issues relating to tax evasion and avoidance by private, wealthy individuals and multinationals (Slemrod and Wilson 2006). Similarly, it has been observed that tax havens (secrecy jurisdictions) have continued to hamper on-going efforts aimed at reducing the tide of IFFs in Africa. It therefore becomes critical to study the roles played by offshore tax havens in facilitating IFFs out of Africa and counter measures to take to mitigate these movements which have been stripping the continent of much needed funds for developmental 
purposes.

Literature is replete with studies on illicit financial flow of funds (IFFs) and several associated variables such as: IFFs and developmental impacts (Herkenrath 2015, Schlenther 2016); IFFs in Africa and policy implications (Onanuga 2018); IFFs and Trade mis-invoicing and Tax avoidance (Forstater 2018); IFFs and FDIs in Africa (Ndikumana and Sarr 2019); IFFs and the mining/extractive industries (Gumede and Fadiran 2018, Igbatayo 2020); IFFs and economic growth and development in Nigeria (Ogbonnaya and Ogechukwu 2017, Chinwe 2018). A close review however shows that there is a dearth of available works that directly studied the linkage between tax havens and the steady stream of IFFs out of Africa despite the fact that the continent remains one of the most resource regions of the world. Furthermore, majority of current works attempting to establish the linkage are those conducted by multilateral agencies essentially as part of their advocacy works (IMF 2011, UNDP 2011, UNECA 2013, OECD 2016). This article therefore builds on existing body of works by focusing on the interrelationships subsisting between tax havens and illicit financial flows with particular reference to Africa.

Accordingly, therefore, the central hypothesis of the work is as follows:

$\mathrm{H}_{0}$ : The use of tax havens has no significant effect on illicit financial flow of funds from Africa.

The remainder of the paper is arranged as follows: Section 2 shows an examination of extant literature from the standpoint of conceptual development, theoretical framework and empirical reviews. Sections 3 and 4 considers the methodology adopted, results and discussion of the research findings while the conclusion and recommendations emanating from the study is presented in section 5.

\section{LITERATURE REVIEW AND THEORETICAL FRAMEWORK}

\section{Illicit Financial Flow of Funds (IFFs)}

The origin of the term 'illicit financial flow of funds' is traceable to the pioneering works of the World Bank in the 1900s who first examined it from the perspective of regular capital flight (Kituyi 2020). As globalization gathered pace alongside the rapid movement of private capital, the phenomenon became a matter of increased concern. The Global Financial Integrity Group (GFI, 2013) defines illicit financial flow of funds (IFFs) as "crossborder transfers of funds that are illegally earned, transferred, or utilized." The United Nations (UN) and the Organization for Economic Co-Operation and Development (OECD) in their combined report of 2016 defines illicit financial flow of funds (IFFs)broadly as "all cross-border financial transfers, which contravene national or international laws. This wide category encompasses several different types of financial transfers, made for different reasons, including: funds with criminal origin, such as the proceeds of crime (for example tax evasion, money laundering, fraud and corruption); funds with a criminal destination, such as bribery, terrorist financing or conflict financing; transfers to, by, or for, entities subject to financial sanctions under UN Security Council Resolutions and its successor resolutions (e.g. Al Qaida and other terrorist organizations); and transfers that seek to evade antimoney laundering/counter-terrorist financing measures or other legal requirements (such as transparency or capital controls)."

Gumede and Fadiran (2018) view illicit financial flow of funds as any illegal and corrupt practice done to acquire money without due process that is in line with international financial and trade regulatory frameworks. Put simply therefore, IFFs refers to illegitimate inter-border movements of funds through the conduct of certain financial activities. Financial activities in this case includes such ventures as cross-border smuggling, counterfeiting, public corruption, drug trafficking, human trafficking and series of tax avoidance schemes. The sources of IFFs can thus be broadly classified into three viz: funds from official/public corruption, tax evasion and criminal ventures.

While there has been a lot of academic debate as to the proper constituents of IFFs and attempts to isolate tax evasion practices from the definitional milieu (Forstater 2018, Cobham and Janský, 2019), it is the considered opinion of this researcher that such a move would be counterproductive as it blurs the line between rational idealism and practical realism. Consequently, for the purpose of this paper therefore, emphasis shall be on IFFs emanating from international trade and taxation. The OECD has expressed serious concerns with what has come to be regarded as base erosion and profit shifting mechanisms which has now become commonplace with foreign owned entities operating in the African continent.

Contrary to popular opinion, recent statistics obtained from the Global Financial Integrity group suggests that while funds flow from international trade and tax evasion accounts for between $60 \%$ to $65 \%$ of total IFFs in Africa, official corruption via bribes and embezzlement accounts for $10 \%$ or less of total IFFs.

The key sources of IFFs are as reflected in the figure below: 


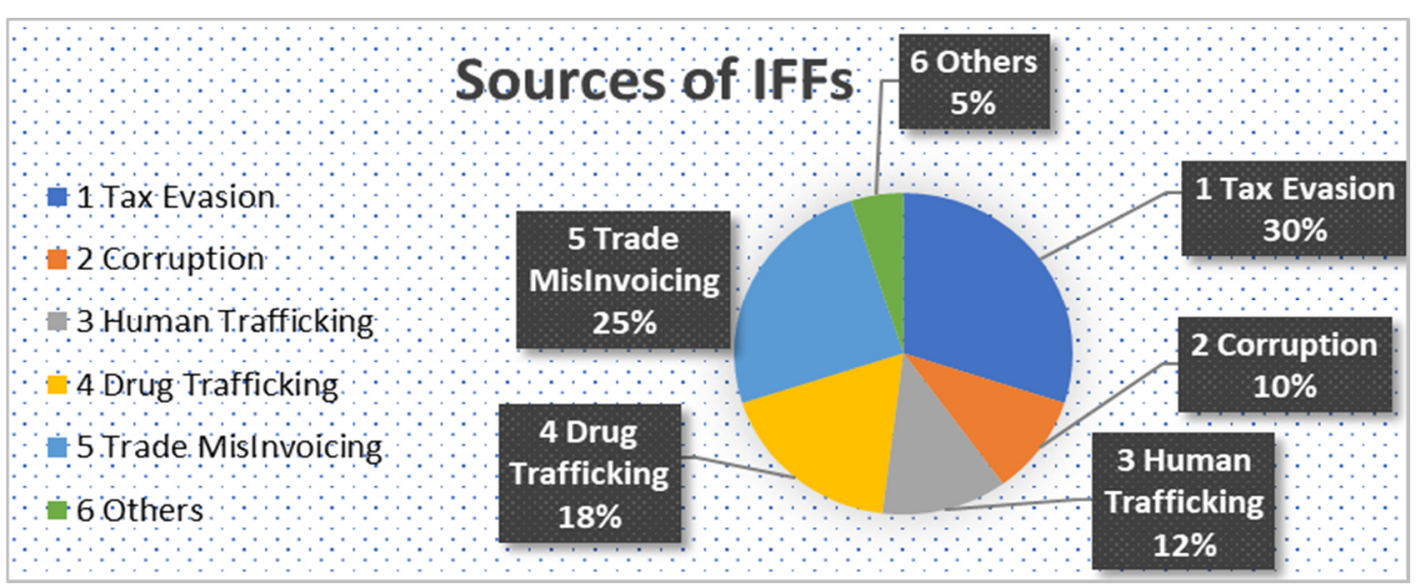

Figure 1: Sources of IFFs in Africa

Source: Adapted from Global Financial Integrity Report (2015)

IFFs also represent massive missed development opportunities for Africa as such funds illegally moved offshore could have been used locally to facilitate the growth and development of the continent. The uniform opinion of experts today is that on the average, Africa loses up to $\$ 88.6$ billion annually to IFFs (UNCTAD, 2020). Abayomi (2018) found that for poor nation states in Africa, IFFs were significantly higher per dollar of GDP generated from such countries. The situation is so precarious that the sum total of financial flows generated from Official Development Assistance (ODA) and Foreign Direct Investments (FDI) in a fiscal year is many times less than the volume of outflows by way of IFFs (Kar and Cartwright-Smith 2010). This implies that for every dollar of development assistance received by developing countries, more than two dollars disappear out of the respective countries' portfolio.

In terms of measurement and objective assessment, there are four methods globally recognized for estimating IFFs. These are the Dooley Method, Hot Money Method, World Bank Residual Method and Trade Mispricing Methods (Kar 2012, UNECA 2015). Of the four methods, the World Bank Residual Model and the Trade Mispricing Method are the more popularly accepted methods adopted for assessment due to their conservative nature and their ability to permit structuring of IFFs (Reuter 2012, Sahadath 2014, Carbonnier and Cadena 2015). However, irrespective of the method used, the overriding conclusion by scholars is that the impact of IFFs on the African continent in volume and value terms has been massive (Reuter 2012, Herkerath 2014, Dolve and Mullard 2019, Signe,Sow and Madden 2020).

In terms of nature and impact, IFFs have become the unfortunate launchpad for communal conflicts and the breakdown of law and order in Africa. Goal 16 of the Sustainable Development Goals (SDGs) of the United Nations (UN) contains a significant worldwide call to action in this regard. The SDGs principle requires that nation states put in place sufficient mechanisms that limits incidences of IFFs through the establishment of effective and workable self-accounting governance structures. This therefore implies that it has a global scope in reach and depth. However, in recognition of its debilitating impact on the African continent, Aspiration 7 of the African Union's (AU's) Agenda 2063 calls on the continent "to take full responsibility for financing its development" and in order to achieve this goal, it must "eliminate illicit financial capital outflows and promote the involvement of civil society organizations to track and bring back any illicit financial capital outflows. IFFs from the extractive industries in Africa is particularly worrisome. Illegal mining of gold, platinum, diamond and other similar solid minerals have resulted in heavy capital flights without commensurate development of the African continent. For example, using countries within the Southern African region as benchmark (Botswana, Namibia, Zimbabwe and South Africa), the studies of Gumede and Fadiran (2018) found that IFFs from the region within a fifteen years period (2000 to 2015 ) amounted to $\$ 11.27$ trillion. The Global Financial Integrity report of 2015 however puts its estimate as $\$ 10.6$ trillion. These were largely due to leakages in the balance of payments of nation states, deliberate under-reporting, under-invoicing and similar other schemes.

The unwarranted consequences of illicit financial flows include among others the following: the hampering of societal cohesion; corruption of public and private investment decisions; reduction of government's ability to provide critically needed public infrastructure and the engendering of widespread poverty and economic inequality. Illicit financial flows of funds (IFFs) out of the African continent have remained a major challenge for member countries despite increased democratization of political leadership. This apparent disconnect between greater institutionalized leadership and reining in the illegal outflow of public funds have continued to command the attention of human development advocates, donor agencies, non-governmental organizations, public finance enthusiasts and academic scholars. 


\section{Tax Havens}

Tax havens owe their origin in the late $19^{\text {th }}$ century and $20^{\text {th }}$ century to the need to step-up post-war reconstruction efforts by attracting foreign capital while still providing financial security to the holders of funds (Dharmapala and Hines 2006, Gomez 2017). In terms of geographical location, they can be categorized broadly into three groups: those located within British owned territories, European territories and Southern American region (Palan, Murphy and Chayagneux 2010).

Tax havens are essentially offshore tax shelters that facilitate the receipt and concealment of illegally obtained financial flows. The European Union (EU) calls it the 'black lists.'Somorin (2012) posits that they are countries or territories which impose low, minimal or no tax to reported earnings and is generally used by business entities to escape tax payments which otherwise would be payable in a high tax country. They are also offshore financial centers with a high degree of financial secrecy involving adoption of customer protective frameworks. These havens serve as secrecy jurisdictions where entities set up shell companies which facilitates large-scale movement of funds out of the original jurisdictions where such trade took place. The main distinguishing feature therefore is their secrecy which further permits a zero or low tax rate, to non-residents or foreign-owned legal entities.

Gomez (2017) opined that tax havens can be classified between those that encourage physical presence of individuals (Eg. Andorra and Monaco), those with bias for multinationals (Eg. British Virgin Islands and Netherlands Antilles) and those with mixed bias for both persons and corporations (Eg, Cayman Islands and the Bahamas).

As tax havens grew in scope and became more brazen in their activities, tax avoidance schemes became more complicated resulting in increasing global concerns for a clampdown on their activities. The European Union (EU) in 2017 subsequently isolated a list of 17 tax havens that were found to be particularly uncooperative with measures put out to discourage profit shifting while improving tax governance, fairness and transparency (Rusina 2020). These blacklisted and non-cooperative tax territories that were named and shamed included American Samoa, Bahrain, Barbados, Grenada, Guam, South Korea, Macau, the Marshall Islands, Mongolia, Namibia, Palau, Panama, St Lucia, Samoa, Trinidad and Tobago, Tunisia and the United Arab Emirates. Subsequent compliance annual reviews have seen several of the originally listed territories removed with the update as at February 2020 indicating a new list of 12 non-cooperative territories: Cayman Islands, Palau, Panama, Seychelles, American Samoa, Fiji, Guam, Samoa, Oman, Trinidad and Tobago, Vanuatu and US Virgin Islands.

There are however divergent views as to the effectiveness or otherwise of these naming and shaming approach adopted by the EU (Guarascio 2017, Lomas 2018, Collins 2020). This is especially so given the accusations of bias and lopsided listing benchmarks against the EU (Songailaite 2020). Notwithstanding these claims, the frequent issuance of these EU blacklists has brought renewed focus on the global clamor for tax justice and fairness.

For the purpose of this study, tax havens are defined to be the 46 countries and jurisdictions listed by the IMF and World Population Review as offshore financial centers (as depicted below):

Table1: Tax Haven Locations and Territories

\begin{tabular}{|c|c|c|c|c|c|c|}
\hline & & & & & & \\
\hline \multicolumn{6}{|c|}{$\underline{\text { Global Tax Havens }}$} & \\
\hline & & & & & & \\
\hline$\underline{S / N}$ & $\underline{\text { Tax Havens }}$ & $\underline{\mathrm{S} / \mathrm{N}}$ & Tax Havens & $\underline{S / N}$ & Tax Havens & \\
\hline & Andorra & 17 & Grenada & 33 & Nauru & \\
\hline & Anguilla & 18 & Guernsey, Sark \& Alderney & 34 & \multicolumn{2}{|c|}{ Netherlands Antilles } \\
\hline & 3 Antigua \& Barbuda & 19 & Hong Kong & 35 & Niue & \\
\hline & Aruba & 20 & Ireland & 36 & Palau & \\
\hline & Bahamas & 21 & Isle of Man & 37 & Panama & \\
\hline & Bahrain & 22 & Jersey & 38 & \multicolumn{2}{|c|}{ Saint Kitts \& Nevis } \\
\hline & Barbados & 23 & Lebanon & 39 & Saint Lucia & \\
\hline & Belize & 24 & Liechtenstein & 40 & \multicolumn{2}{|c|}{ Saint Vincent \& the Grenadines } \\
\hline & Bermuda & 25 & Luxembourg & 41 & Samoa & \\
\hline 10 & British Virgin Islands & 26 & Macao & 42 & Seychelles & \\
\hline 11 & Cayman Island & 27 & Malayisa & 43 & Singapore & \\
\hline 12 & Cook Islands & 28 & Malta & 44 & Switzerland & \\
\hline 13 & 3 Costa Rica & 29 & Marshall Islands & 45 & \multicolumn{2}{|c|}{ Turks \& Caicos Islands } \\
\hline 14 & Cyprus & 30 & Mauritius & 46 & Vanuatu & \\
\hline 15 & Dominica & 31 & Monaco & & & \\
\hline 16 & Gibraltar & 32 & Montserrat & & & \\
\hline & & & & & & \\
\hline & & & & & & \\
\hline
\end{tabular}

Source:IMF and World Population Review (2021) 
According to the 2021edition of the Tax Justice Network report, ten (10) of the above listed tax havens have now become the world's greatest enablers of corporate tax abuse and popular destinations for the concealment of IFFs. These are as shown below:

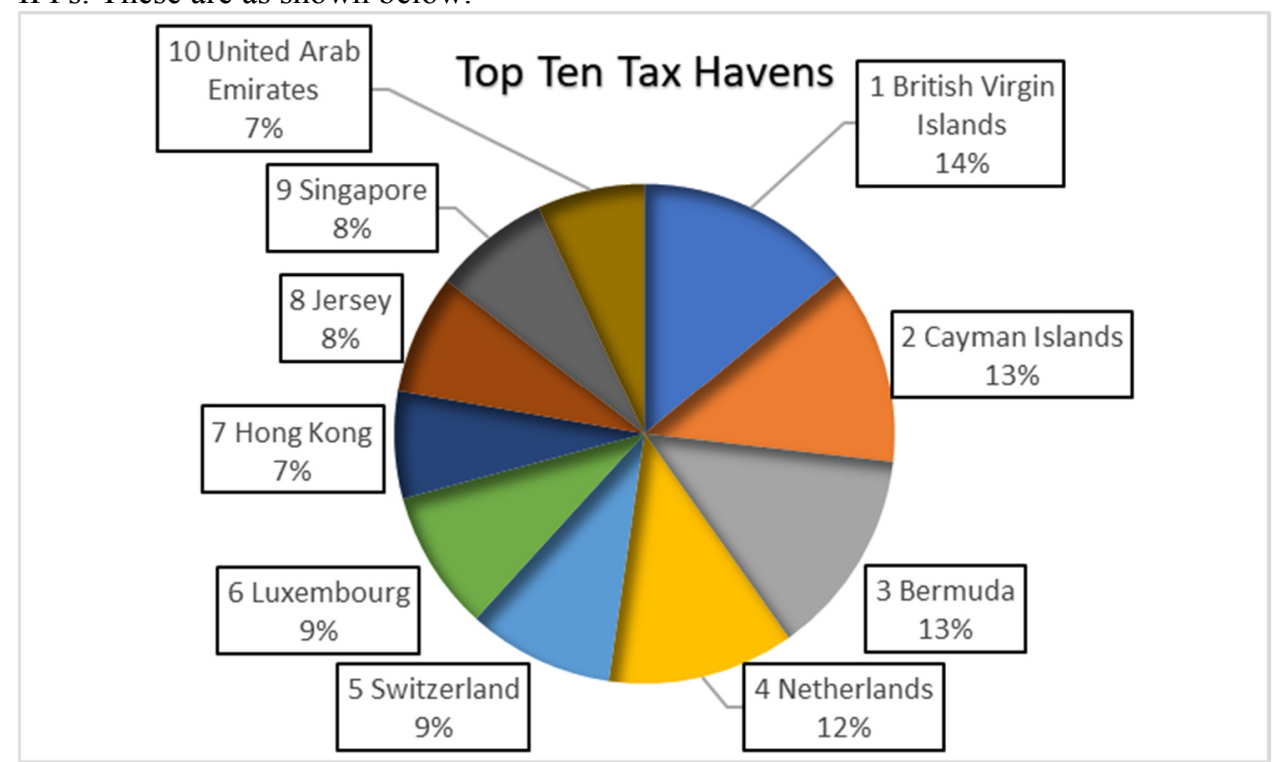

Figure 2: Top 10 Tax Havens for IFFs (2021)

Source: Tax Justice Network (2021)

Available documentary evidence suggests that at least $60 \%$ of world trade is carried out by multinational corporations (MNCs) through their network of branches, affiliates, subsidiaries and franchisees located all over the world. Due to the nature of these extensive networks, these MNCs develop complex transfer pricing mechanisms that enable them to evade taxes in the territories' where they originally carried out their businesses. The end result is that some of the profits which ordinarily should have been retained in the respective host countries are freighted away thus depriving such countries of opportunities for more inclusive development.

Tax havens or secrecy jurisdictions also operates by encouraging investments in the offshore financial center through the establishment up of holding company structure in which the principal business of the entities is carried out in countries (e.g. in Africa) other than the tax havens. This model is also called ring-fenced legislation as it forbids the carrying out of business except nominal board of directors' meetings in the tax haven. This therefore ensures that little or no tax is paid in the tax haven.

It has also been observed that tax havens provide unfortunate incentive for breaching requisite regulations and consequently have negative effect on the economic growth of developing countries of which the African continent is most affected.

\section{Tax Havens \& IFFs -A Nexus}

The major nexus between tax havens and IFFs is that tax havens are usually the countries of destination of illicit financial flows. In fact, it can be argued that there is no greater enabler of economic disparity between Africa and the developed world than the unwitting blend of illicit financial flows and offshore tax havens.

There have been at least seven (7) major leaks relating to tax havens and illicit financial flow of funds over the years. These include WikiLeaks(2010), Offshore Leaks (2013), Luxembourg Leaks(2014), Swiss Leaks (2015), Bahamas Leaks (2016), Panamas Papers (2016) and Paradise Papers (2017) respectively. Of the seven major whistle blowing, Panama Papers and Paradise Papers are the most conspicuous in terms of the impact, scope and the nature of their key findings. Consequently, this paper shall concentrate principally on these two.

The Panama Papers represent one of the world's greatest leaks of documents containing financial information about how the rich, wealthy and powerful in the society have used tax havens to launder money and evade taxes. The documents were obtained by a German newspaper in 2016 from a law firm based in Panama called Mossack Fonseca. The document discovery was eventually passed to the International Consortium of Investigative Journalists (ICIJ) who then brought it to the attention of the world in January, 2017. The Panama Papers covered the period of 1977 to 2015 and according to the ICIJ, in terms of recoveries, only about $\$ 1.2$ billion has been recovered by way of fines and back taxes till date.

The $11.5 \mathrm{~m}$ secret files of documents taking up over 2,600 Gigabytes worth of data space is unprecedented in scope, content and sheer volume. A review of the documents shows that it contains details of over 214,000 entities (including companies, trusts and foundations) while over 12 former or current world leaders were implicated in the reports. These include the Presidents of China, Russia, Argentina, Australia, Ukraine, Iceland etc. Majority of 
those implicated were found to have floated offshore shell companies (over 15,000) through the law firm to conceal their wealth and evade taxes. The law firm used about 21 tax havens and acted on behalf of over 140 politicians covering at least 50 countries in the world. For Nigeria, a number of persons including Dr. Saraki, Senator David Mark, General Danjuma, James Ibori among others were mentioned. The report specifically indicted the former Governor of Delta State - James Ibori who is said to have laundered over \$250m through a network of offshore shell companies. He has since pleaded guilty in a UK Court and about $\$ 5.8 \mathrm{~m}(4.2 \mathrm{~m}$ GBP) has recently been returned to Nigeria even though there are on-going back and forth between the Federal Government and the State Government as to who should be correct recipient of the funds.

A snapshot of the key details relating to the Panama Papers is presented hereunder:

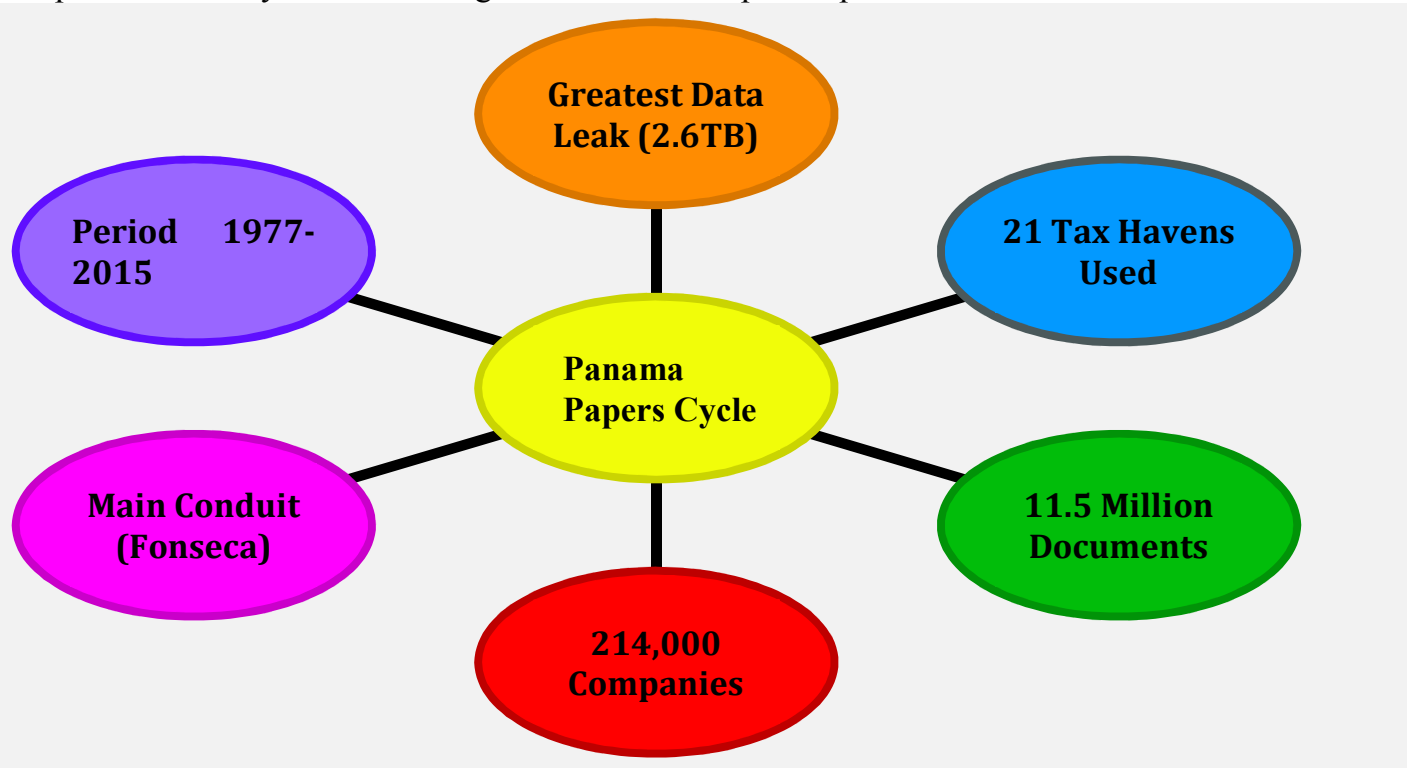

Figure 3: The Panama Papers (Snapshot)

Source: Adapted from International Consortium of Investigative Journalist Report (2017)

The Paradise Papers is also another expose of how the rich and powerful tried to evade taxes using tax havens. Similarly, the documents were also obtained by a German newspaper and passed on to the International Consortium of Investigative Journalists (ICIJ) who then brought it to the attention of the world in November, 2017.

The $13.4 \mathrm{~m}$ secret files of documents taking up over 1,400 Gigabytes worth of data space is linked principally to a law firm called Appleby and covered the period between 1950 to 2016 . The company at the center of the leak - Appleby was founded in Bermuda and had been in operation since the 1890s as a specialist offshore legal firm serving multitudes of clientele cutting across politicians, celebrities, corporations, financial institutions and highnet-worth individuals. The law firm used about 19 tax havens and acted on behalf of over 100 multinationals including Apple, Nike and Botox-maker Allergan.

Appleby also used similar tactics like the Panama legal firm (Fonseca) by assisting its clients to set up and register offshore shell companies with the objective of laundering money, concealing wealth and consequently evade legitimate taxes. Popular figures mentioned in the report include Queen Elizabeth and Prince Charles of United Kingdom (UK) respectively and some key officials of the administration of the former U.S President Donald Trump. Dr. Bukola Saraki and Africa's richest man - Aliko Dangote are among the major Nigerians mentioned in the report.

According to the ICIJ 2017 report, the two principal findings were as follows: first, it provided explicit details of how the world's largest commodity trader (Glencore) worked with local collaborators to siphon monies from illegal mineral resources trade in the Democratic Republic of the Congo. Secondly, it also provided explicit details of how some wealthy private individuals used the Isle of Man to reduce their individual tax liabilities.

A snapshot of the key details relating to the Paradise Papers is presented hereunder: 


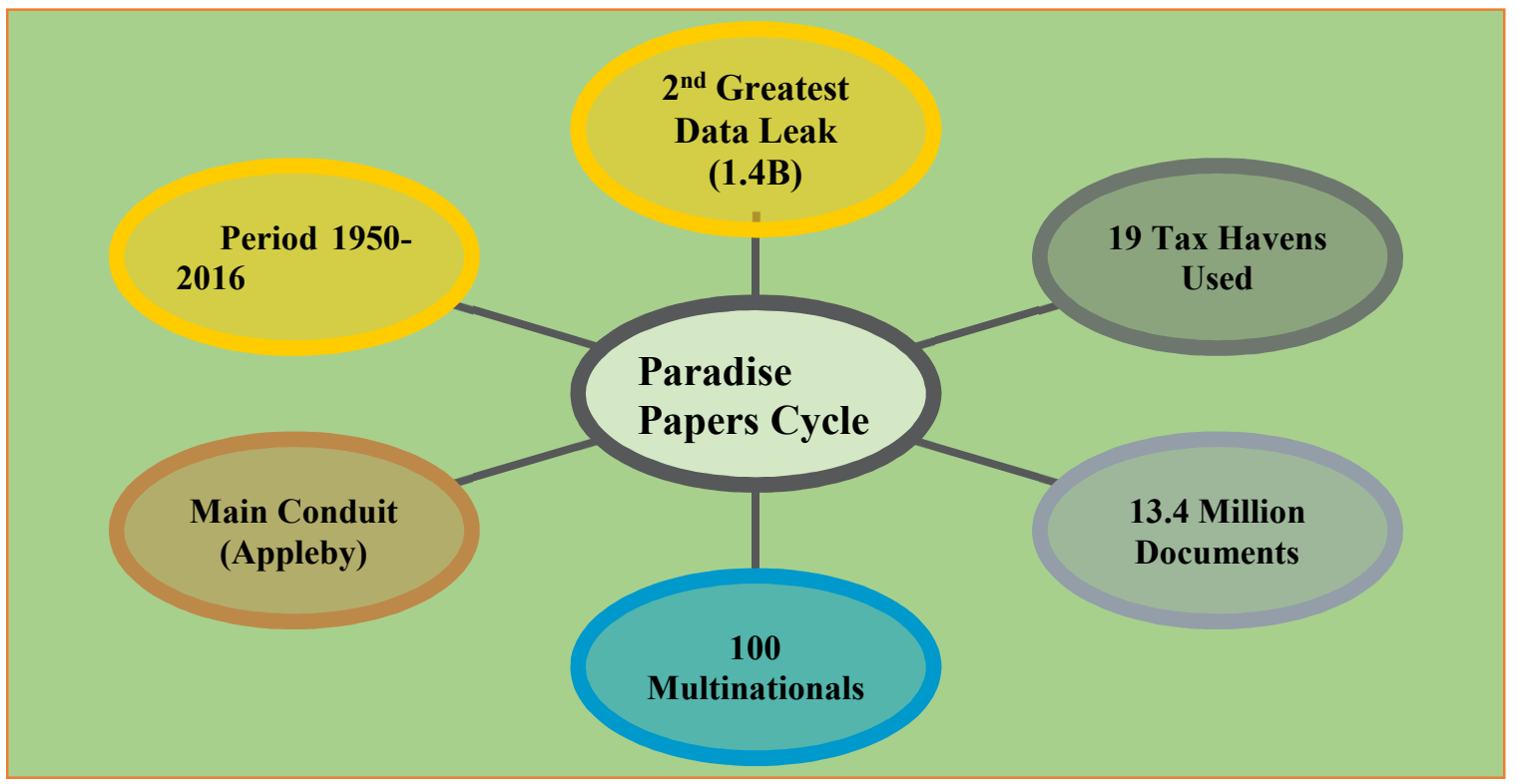

Figure 4: The Paradise Papers (Snapshot)

Source: Adapted from International Consortium of Investigative Journalist Report (2017)

According to the African Development Bank (2013), one of the major impacts of IFFs is that they widen funding deficit relating to the development of individual African countries. For example, in a study conducted involving thirty-nine (39) selected African countries, Ndikumana (2013) found that between 2000 and 2010, in the absence of IFFs, the sampled countries would have secured at the minimum an average economic growth rate of $3 \%$ on a YOY basis. This forecast growth rate would have risen further to a minimum of $3.9 \%$ for oil exporting countries thus underscoring the need to do it all takes to cut down incidences of IFFs.

The major role played by tax havens in facilitating IFFs is that they encourage the setting up of structured tax systems which entails provision of little or inadequate information about an entity and consequently concealment of financial flows. Furthermore, such locations provide little or no incentive for enforcing tax legislations. The existence of loopholes in the tax systems of such jurisdictions further provide impetus for the movement of illicit financial public and private capital as the platform is provided for the concealment of beneficial ownership of accounts and assets.

\section{Theoretical Framework}

This study opted for the portfolio choice theory as the underpinning theory because of its consistency with many prior studies which showed that holders of funds will naturally move investible funds where relative to associated risks, they can secure maximum returns. The theory owes its origin to the works of Markowitz (1952).The theory assumes investors of funds are generally risk averse and that once ownership of assets has been secured, rational thinking individuals will seek out the best outlet to move such funds with a view to preservation of values and hence minimization of risks. The theory is known to be the precursor of the capital assets pricing model often associated with investments. Major supporters of the theory include Hubbard (2007) and Sabbadini (2010) who affirm the applicability of the theory to both financial and non-financial investments.

Critics of the theory have however pointed to the fact that some of its assumptions such as rationality and estimations of expected returns based on historical parameters may be detached from everyday realities (Low, Faff and Aas 2016; Hui, Fox and Gurevitch 2017). Nevertheless, in the view of this researcher, this theory is considered germane for this study for a number of reasons. First, the chief rationale for the movement of funds by multinationals from regions of high tax regime to those with low or minimal tax is to increase overall profitability, a practice that has been termed profit shifting. Secondly, the theory does not concern itself as to the legality or otherwise of beneficial ownership of funds. Thus, as long as funds are in the custody of an entity or private individual, they are at liberty to consider the best portfolio option to maximize available returns.

\section{Empirical Review}

There have been a number of empirical studies on the subject of illicit financial flow of funds especially as it relates to the impact of tax havens and associated variables. Some of these alongside their findings are briefly discussed hereunder.

Signe, Sow and Madden (2020) carried out an extensive study on IFFs in Africa with specific focus on identifying the key drivers, destinations and policy options available to decision makers in the continent. The 
research discovered that higher tax rates supported by increased inflation facilitate increased IFFs out of the African continent. Additionally, increases in trade between Africa countries and China also engender increased IFFs out of the continent suggesting possible exploitation of the weak institutional and regulatory framework prevalent in the partner countries.

Rusina (2020) undertook a unique study focusing on the impact of tax havens on firms' value especially under conditions of naming and shaming of affected tax havens. The researcher found that firms found to maintain overseas subsidiaries and/or affiliates in the tax havens that were blacklisted by the European Union in 2017 witnessed rapid deterioration in their market valuation in excess of \$56billion. The implication therefore is that negative market sentiments overwhelming impact firm valuation and consequently investors' confidence in the affected entities.

Ndikumana and Sarr (2019) investigated the nexus between capital flights, foreign direct investment and the exploitation of natural resources in Africa. The researchers utilized data extracted from thirty (30) African countries covering the period of $1970-2015$. The key finding of the work was that in periods of sustained GDP growth arising from better usage of natural resources, capital outflows from Africa still remained high thus implying that positive rate differentials was not sufficient to encourage portfolio investment in Africa. Illicit financial movement of funds to outside territories therefore still occurs due to leakages and weak institutional frameworks.

Gumede and Fadiran (2018) explored the socio-economic implications of IFFs as it related to selected countries in Southern Africa. The researchers used the mining sector as a proxy to explain the extent of the impact of IFFs in South Africa. Panel data used for the study was extracted mainly from the database of the United Nations (UN Comtrade) while data analysis was accomplished via the unit test and Augmented Dickey-Fuller approach. The outcome of the research was to the effect that IFFs had negative impact on the socio-economic wellbeing of the sampled countries. Consequently, the study recommended an urgent need to build up capacities as well as strengthen existing regulations to mitigate the challenge.

Ogbonnaya and Ogechukwu (2017) conducted a study on the effect of illicit financial flow of funds on the economic growth and development in Nigeria using data obtained from Nigeria's monetary regulator - Central Bank and estimates extracted from the Global Financial Integrity group. Data collected covered a 35 years period from 1980 to 2015 and was validated using the unit root and co-integration tools. The study established that IFFs had a significant negative effect on economic growth and development in Nigeria. To curb continuous IFFs, it recommended greater collaboration and cooperation among countries in Sub Saharan Africa with a view to jointly confronting and exposing the menace.

Onanuga (2018) undertook a comparative study of IFFs in selected African countries with particular focus on the implications for policy decision making. Seven African countries selected using the purposive sampling technique constituted the sample of the study while data collected related to a ten-year period covering 2005 to 2015. The research found that IFFs as a proportion of GDP was highest in low income countries relative to their middle-income counterparts. To stem the tide of IFFs from all national income categories, the study recommended that nation states should put in place strong and workable regulatory controls.

Herkenrath (2015) assessed IFFs in developing economies with reference to the social and political impacts. The study focused on extensive review of existing scholarly and non-academic literatures to draw its conclusions and recommendations. Specifically, the study found that the socio-political consequences of IFFs on developing economies such as Africa includes providing veritable platforms for organized crimes, rent seeking and corruption while worsening existing societal inequalities. To address the challenge, the research advocated for greater international cooperation and collaboration.

Forstater (2018) studied the interplay between IFFs, trade mis-invoicing and tax evasion practices of multinationals globally. The study represents a novel attempt to quantify the impact of trade mis-invoicing as it affects nation states. It provided empirical evidence for the estimation of trade mis-invoicing values from developing countries while also elaborating on measures taken by multinationals to escape in-built capital controls in the affected countries.

Ahmed, Jones and Temouri (2020) evaluated the relationship subsisting between the use of tax havens by multinationals and the extent of foreign direct investment into emerging economies of which Africa is a key beneficiary. The study utilized panel data obtained from multinationals (MNCs) operating in 19 developed countries covering the period 2009 to 2017. The study revealed that MNCs that operate in Africa are 5.3 times more likely to move funds to tax havens than others that do not operate in Africa. The research therefore concluded that illicit financial flow of funds out of developing countries is facilitated by weak institutions and imperfect markets in such countries. We note that these findings are also consistent with the studies of (Cobham, Jansky and Meinzer 2015) and Zucman et al (2016) who measured the extent of profit shifted out of developing countries to the safe harbor of tax havens.

Mugarura (2018) examined the interconnection between tax havens, offshore financial centres and the current sanctions regime with particular reference to developing countries. The study adopted the case studies design 
methodology and found that there exists a close linkage between tax havens and the rise in tax evasion and money laundering schemes. The paper recommended the need to reinforce and faithfully implement the sanctions regime globally to stem the tide of financial crimes.

Pale (2018) assessed the impact of tax havens on the proper functioning of developing countries. The study adopted a systematic review approach to data gathering and analysis involving available peer reviewed academic journals. The study revealed that tax havens impede the revenue generating abilities of developing countries due to revenue losses orchestrated by illicit financial movement of funds offshore. This view is also corroborated by the works of Fuest and Riedel (2010).

\section{METHODOLOGY}

The methodology adopted for this work is qualitative design anchored on content analysis of previous work done supported by empirical review of secondary data. Secondary source of data of forty-four (44) African countries covering the period 2005 to 2014 were obtained from the United Nations (UN), International Monetary Fund (IMF), Global Financial Integrity (GFI) and other similar development finance institutions. These were reviewed, synthesized and analyzed to produce the discussed results.

\section{DATA ANALYSIS, RESULTS AND DISCUSSION}

Figure 5 showed that within the period under review, for each dollar of trade consummated, Africa (especially Sub-Saharan Africa) loses more that $7.5 \%$ as IFFs out of the region. Similarly, the continent ranks highest as the territory with the highest attrition resulting from IFFs. The implication of this is that critical resources needed to facilitate rapid development and improvement in the Human Development Index (HDI) is lost. When extended to 2018 , the attrition rate is higher as over $\$ 1.3$ trillion is said to have left the shores of Africa illegally (Signe, Sow and Madden 2020).

Furthermore, within the first two (2) years of the study period, the three key West African states (Nigeria, Ivory Coast and Ghana) within the Sub Saharan Africa grouping lost at least the sums of $\$ 821 \mathrm{~m}, \$ 260 \mathrm{~m}$ and $\$ 121 \mathrm{~m}$ respectively to trading partners in the US and EU through trade mispricing (Christian Aid 2009). This situation is worsened by the apparent poor institutional framework and lack of proper oversight on the part of regulators in the affected countries.

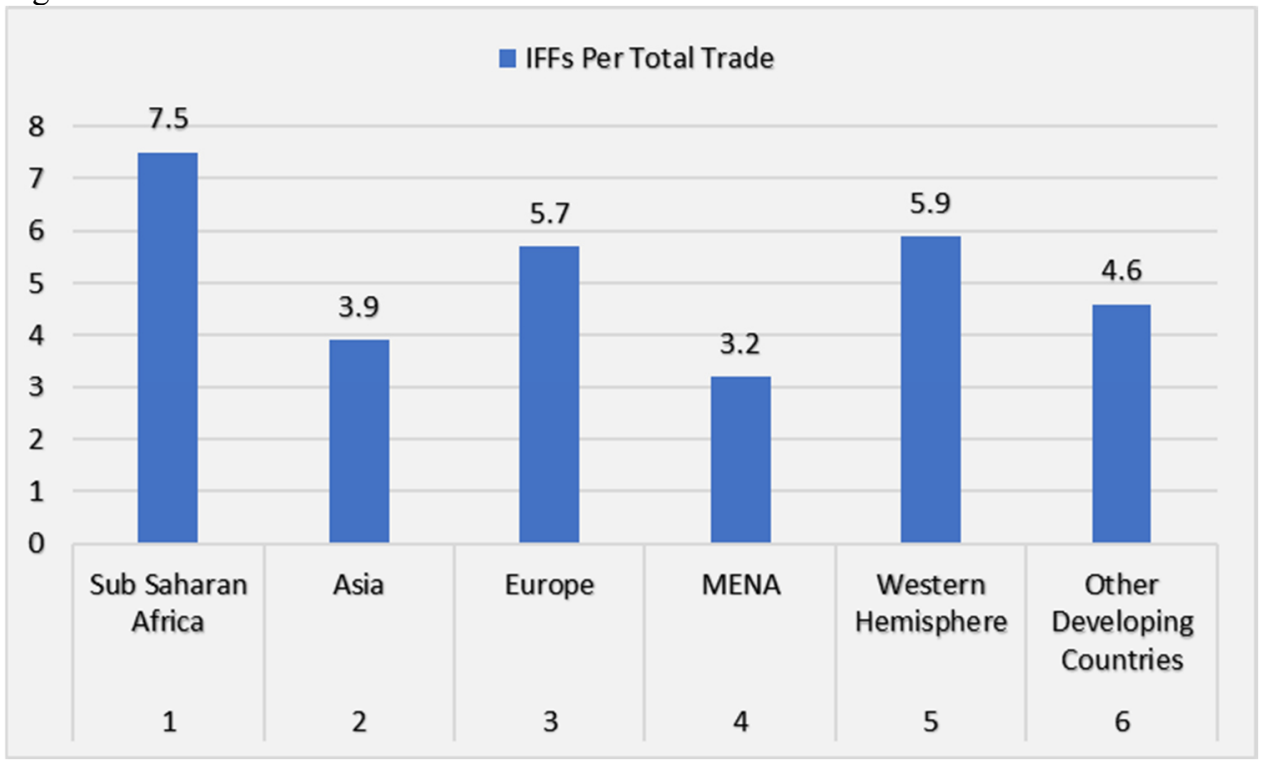

Figure 5: IFFs in Africa Vs. Rest of the World (2005 -2014)

Source: Adapted from IMF and Global Financial Integrity Reports(2015)

NB

* Western Hemisphere - North America, South America, the Caribbean and Central America

* MENA - Middle East and North Africa

* Total Trade is defined as total exports and imports generated within a defined period.

The picture also become even clearer when IFFs out of Africa is considered on a regional basis as shown below. From the analysis, it can be deduced that about $66 \%$ of all African IFFs are traceable to precisely two regions within the continent: The West African region (38 per cent) and the North African region (28 per cent) while the other three regions make up the balance. Furthermore, the analysis indicates the overriding importance of the contribution to IFFs made by oil exporting countries which are found majorly in these two regions. For example, Nigeria which is the dominant oil exporter in the West African region accounts for the largest share of 
IFFs in the region (approximately 79\%) while Algeria and Egypt representing the North African region takes up approximately two-thirds of all illegitimate capital flows from the region (AFRODAD 2015). This position supports the notion that the unbridled scrambling by the West for the abundant natural resources prevalent in Africa is a major causative factor for the continued rise in IFFs out of the continent (Sahadeth 2014).

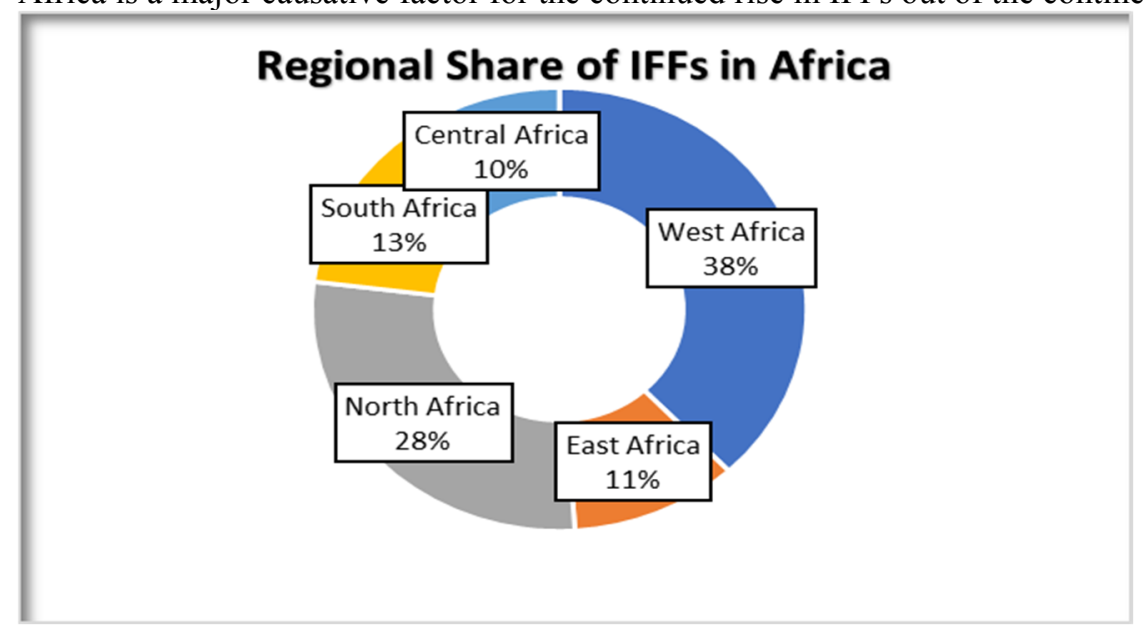

Figure 6: Regional Analysis of IFFs in Africa (2005 - 2014)

Source: Adapted from United Nations Economic Commission for Africa Report (2015)

Figure 6 on the regional share of IFFs in Africa is also in alignment with the joint reports of the AFDB and GFI who asserted that within this period, Africa even merged as net creditor of funds to the developed West which ends up in tax havens. In particular, very good examples exist with dictators and leaders from the African continent. Mobutu Sese Seko of the Democratic Republic of Congo (DRC) stole so much from the country and hid the wealth in tax havens throughout the duration of his regime between 1965 and 1997. Sani Abacha who ruled Nigeria is estimated to have misappropriated more than \$5 billion directly from Nigeria's till between 1993 and 1997 , concealing the funds in tax havens located in Jersey, Liechtenstein, Switzerland and the UK out of which only about $\$ 3$ billion has been repatriated to date. Apart from depriving nation states of resources needed for development, continued pilferage of this nature and illicit financial outflows of same to tax havens serve as disincentive for savings and investment in the local economies (Nkurunziza, 2012).

\section{Africa IFFs To Tax Havens}

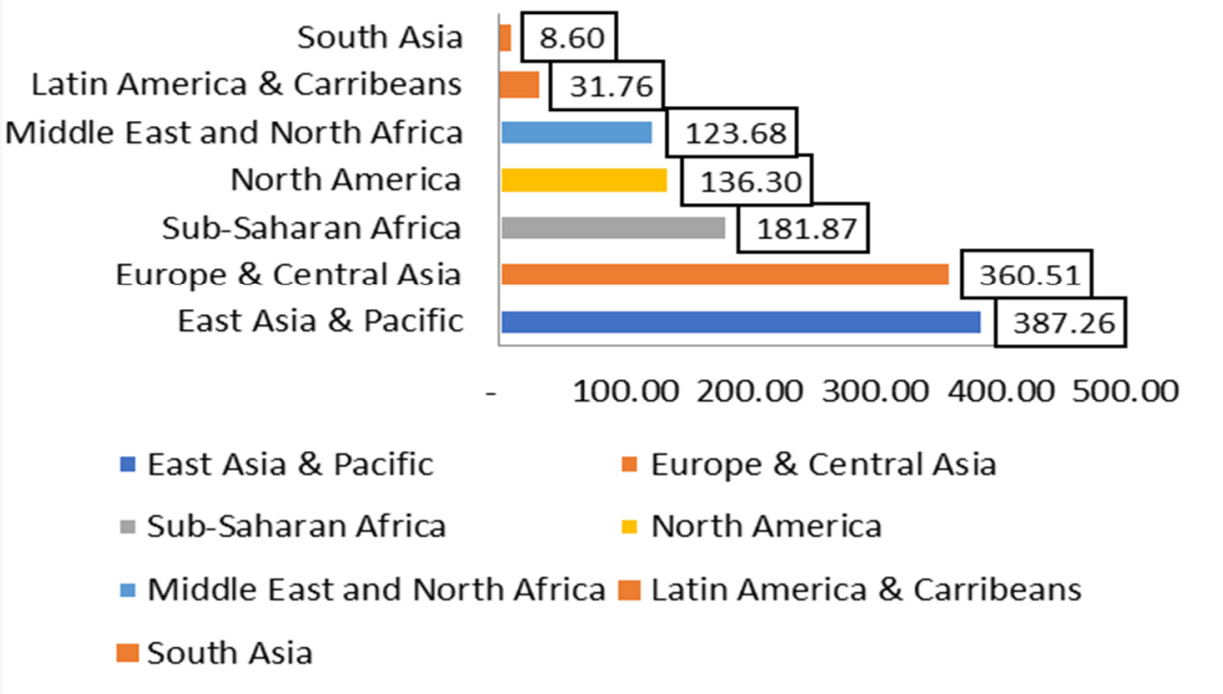

Figure 7: Africa IFFs to Tax Havens (2000 - 2018)

Source: Adapted from Signe, Sow and Madden (2020)

In terms of destination, Figure 7 shows that the majority of illicit financial flows from Africa between 1980 and 2018 have found their way into Europe, Central Asia, East Asia and Pacific regions where majority of tax havens are located as indicated above. Specifically, it can be observed that out of the total of about $\$ 1.3$ trillion IFFs, $\$ 747$ billion representing $60 \%$ went to these regions alone. From available statistics, the top four emitters of illicit financial flows are South Africa, the Democratic Republic of the Congo, Ethiopia, and Nigeria and 
collectively account for over 50 percent of total illicit financial flows from Africa (Signe, Sow and Madden 2020). When localized, statistical data from Nigeria show that the trend of outflows is yet to abate as demonstrated in Table 2:

Table 2: Funds Flow from Nigeria to Tax Havens (2007-2011)

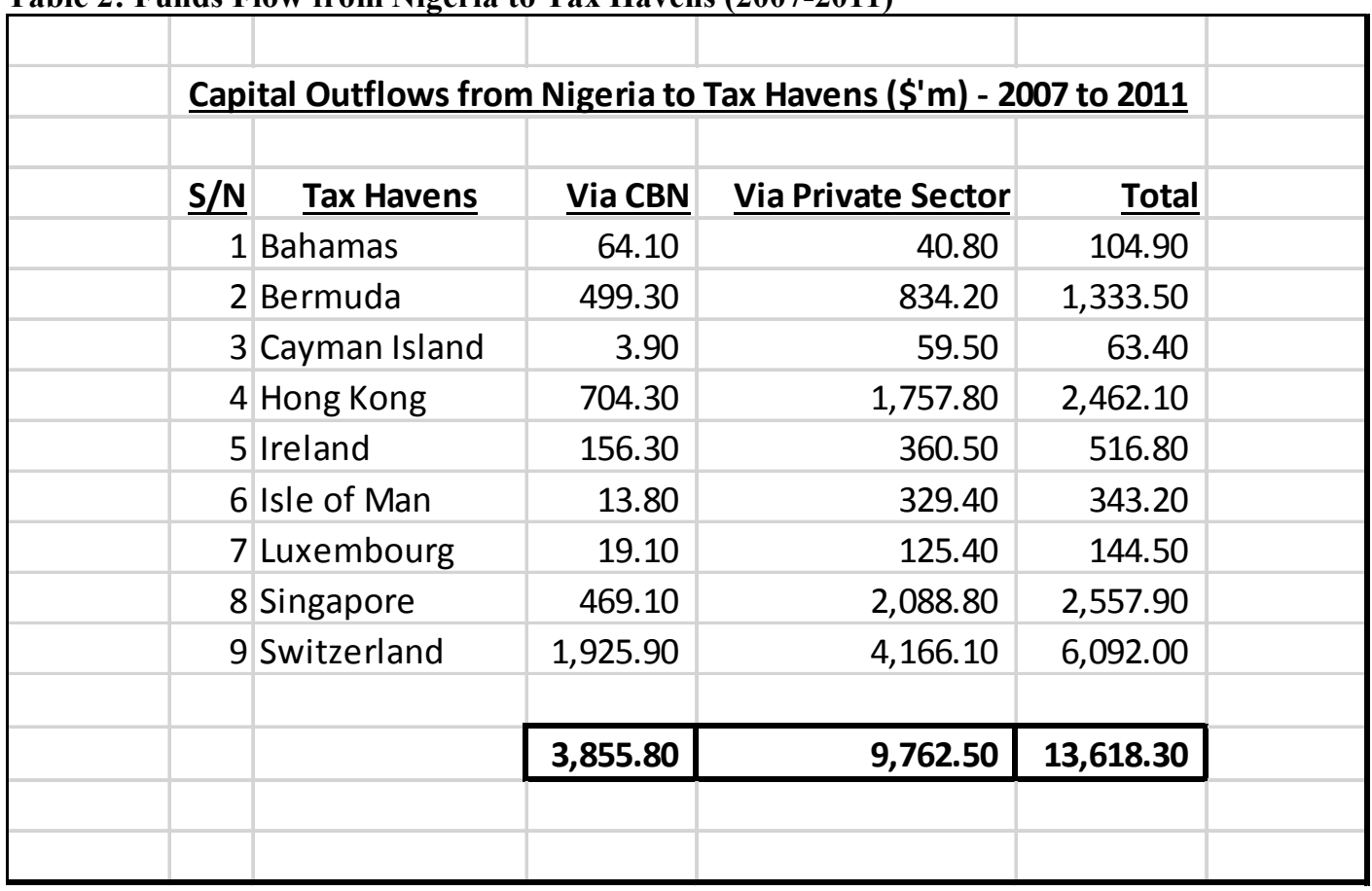

Source: Adapted from Global Financial Integrity Report and Central Bank of Nigeria (2015)

Table 2 shows that the most popular tax haven for the destination of funds from Nigeria is Switzerland accounting for $44.7 \%$ of total outflows. Similarly, the data also shows that private sector funds movement by multinationals and private individuals far exceeds (71.6\%) that by the government through the Central Bank. This validates the earlier proposition in this paper that official corruption accounts for far less IFFs than outflows via tax evasion and trade mis invoicing perpetrated by multinationals.

Even though IFF remains a global challenge especially with the rapid liberalization of financial markets and the ease of movement of private capital, the scale of impact is most felt in developing economies of which Africa features prominently. This is especially so given the smaller resource base and the dysfunctional nature of African economies.

To effectively combat IFFs out of Africa, a key requirement is the demonstration of strong political will on the part of African leaders. This is because without it, the series of legal, economic and judicial means for preventing and/or combating IFFs will not succeed. The GFI further assert that the most effective way to limit illicit financial flows is to increase global consensus, improve financial transparency in nation states as well as developing and implementing targeted strategies to:

- Detect and deter cross-border tax evasion;

- Eliminate anonymous shell companies;

- Strengthen anti-money laundering laws and practices;

- Work to curtail trade mis-invoicing; and

- Improve transparency of multinational corporations

Recently in June 2021, a major breakthrough in the fight to curb IFFs emptying into tax havens was accomplished. The Finance Ministers of the G-7 (Group of seven most industrialized nations) met and agreed to implement a global minimum corporate tax of $15 \%$ for all business entities. This landmark decision which has subsequently been ratified by the meeting of the respective Heads of State amounts to a watershed moment. This is because in the view of the researcher, the decision is capable of creating less incentive for movement of funds to tax havens.

\section{CONCLUSION AND RECOMMENDATION}

This study set out to explore theoretically the nexus that exists between tax havens and the illegitimate flow of funds out of Africa. The study showed that IFFs out of Africa which terminates in tax havens represents massive missed development opportunities for inclusive growth in the continent. The paper identified absence of political will, weak institutional framework, poor regulatory oversight and the unbridled scramble for the continent's 
mineral resources as some of the key factors responsible for the continued rise in IFFs from Africa. The study also found that the absence of global consensus on the proper treatment of tax havens remains a challenge to fostering the needed international collaboration to fight the scourge.

The study recommends that critical stakeholders like the press and civil society groups in their position as public watchdogs must do more to track and report incidences of IFFs in a timeous manner. Similarly, political leadership on the continent must show accountability in the management of public funds while also demonstrating the needed political will to transparently implement the various countermeasures put in place by regulators. Also, on the international front, efforts must be made to ensure that the proposed new minimum, global tax rate of $15 \%$ is adhered to as a needed first step to discourage funds flow to tax havens.

\section{References}

Abayomi O., (2018). Comparing the Illicit Financial Flows in Some African Countries: Implications for Policy.African Journal of Economic Review. 6(2) 172-186

AfDB (African Development Bank) and GFI (Global Financial Integrity) (2013) Illicit Financial Flows and the Problem of Net Resource Transfers from Africa: 1980-2009 (Tunis: AfDB)

African Forum and Network on Debt and Development (AFRODAD) (2015). Illicit Financial Flows in Africa: Trends and Patterns.

Carbonnier G., and Cadena A.Z.,(2015). Commodity Trading and Illicit Financial Flows“, International Development Policy. Open Edition Journal.

Chinwe C. P., (2018). Illicit Financial Flow a Cog in the Wheel of Political and Economic Development of Nigeria.Journal of Public Administration and Social Welfare Research. 3(2):38-54

Christensen J., (2017).The Looting Continues: Tax havens and Corruption. Critical Perspectives on International Business Journal.7(2):177-196

Christian Aid (2009). False Profits: Robbing the Poor to Keep the Rich Tax-free, March Report.

Cobham, A., Janský, P., and Meinzer, M. (2015). The financial secrecy index: Shedding new light on the geography of secrecy. Economic Geography Journal.91(3), 281-303

Cobham A and Janský P (2019). Measuring misalignment: The location of US[United States] multinationals' economic activity versus the location of their profits. Development Policy Review Journal. 37(1):91-110

Collins M., (2020). Did the EU's attempt to name and shame tax havens into behaving better work? Brookings

Dolve M.H, and Mullard S., (2019). Addressing illicit financial flows for anti-corruption at country level. A Primer for Development Practitioners. U4 Anti-Corruption Resource Centre, Chr. Michelsen Institute.

Dharmapala, D. and J. R. Hines, Jr. (2006) “Which Countries Become Tax Havens?” NBER Working Paper \#12802

Forstarter M (2018). Illicit financial flows, trade misinvoicing and multinational tax avoidance: The same or different? Policy Paper No. 123. Centre for Global Development

Fuest C.,and Riedel N., (2010). "Tax Evasion and Tax Avoidance in Developing Countries: The Role of International Profit Shifting," Working Papers 1012, Oxford University Centre for Business Taxation.

GFI (Global Financial Integrity) (2013) Explore the Data: Illicit Financial Flows from Developing Countries 20022011. How to Read the Report's Findings (Washington, D.C.: GFI)

GFI (Global Financial Integrity) (2015). Financial Flows and Tax Havens: Combining to Limit the Lives of Billions of People. Washington DC, USA

Guarascio, F. (2017, November 7). EU tax havens blacklist seen in December, but enforcement unclear. The Reuters

Gumede V., Fadiran D., (2018). Illicit Financial Flows in Southern Africa: Exploring Implications for Socioeconomic Development.Africa Development Journal. 93(4):127-153

IMF (International Monetary Fund) (2011) Revenue Mobilization in Developing Countries, paper prepared by the Fiscal Affairs Department (Washington, D.C.: International Monetary Fund).

Gomez N.G., (2017). The History, Evolution and Future of Tax Havens. Bachelors Thesis. Universitat Jaume I, Barcelona, Spain

Herkenrath M., (2015) "Illicit Financial Flows and their Developmental Impacts: An Overview”, International Development Policy

Hubbard D., (2007). How to Measure Anything: Finding the Value of Intangibles in Business. Hoboken, NJ: John Wiley \& Sons

Hui, C.; Fox, G.A.; Gurevitch, J. (2017). "Scale-dependent portfolio effects explain growth inflation and volatility reduction in landscape demography". Proceedings of the National Academy of Sciences of the USA. 114 (47): $12507-12511$

Igbatayo S.A., (2020). Combating Illicit Financial Flows from Africa's Extractive Industries and Implications for Good Governance. Africa Development Journal. 44(3): 55-86

Imiera P.P., (2020). The corruption race in Africa: Nigeria versus South Africa, who cleans the mess first? De Jure 
Law Journal 53(1), 70-90

Kar, D. and D. Cartwright-Smith (2010).Illicit Financial Flows from Africa: Hidden Resources for Development.Global Financial Integrity Report, Washington DC, USA

Kituyi M., (2020). Tackling Illicit Financial Flows for Sustainable Development in Africa.United Nations Conference on Trade and Development (UNCTAD).Economic Development in Africa Report.1-248

Lomas U., (2018).EU announces sanctions for 'Blacklisted' countries. https://www.tax-news. com.

Low, R.K.Y.; Faff, R.; Aas, K. (2016). "Enhancing mean-variance portfolio selection by modeling distributional asymmetries" (PDF). Journal of Economics and Business. 85: 49-72.

Markowitz, H.M. (1952). "Portfolio Selection". The Journal of Finance. 7 (1): 77-91

Mugarura N., (2018).Tax havens, offshore financial centres and the current sanctions regimes. Journal of Financial Crimes. 24(2):200-222

Ndikumana, L. (2013) Capital Flight and Tax Havens: Impact on Investment and Growth in Africa, Contribution to the European Development Network (EUDN) Conference on 'Finance and Development', Berlin, 11-13 December.

Ndikumana, L. and Sarr M., (2019) Capital Flight, Foreign Direct Investment and Natural Resources in Africa: University of Massachusetts, Department of Economics, Working Paper, No. 2019-12

Nkurunziza, J. D. (2012). Illicit Financial Flows: A Constraint on Poverty Reduction in Africa. Association of Concerned Africa Scholars Bulletin, 87

Onanuga A., (2018). Comparing the Illicit Financial Flows in Some African Countries: Implications for Policy.African Journal of Economic Review.7(2)127-186

Ortega, B., Sanjuán, J. \& Casquero, A., (2020).Illicit financial flows and the provision of child and maternal health services in low- and middle-income countries. BMC International Health and Human Rights Journal.20(15): $15-31$

OECD (Organisation for Economic Co-operation and Development) (2016) Measuring OECD responses to illicit financial flows (Paris: OECD).

Pale R.O., (2018). Tax transparency: Impact of Tax Havens on Developing Countries. Masters' Thesis. University of Pretoria.

Palan, R., R. Murphy and C. Chavagneux (2010) Tax Havens: How Globalization Really Works (Ithaca, NY, and London: Cornell University Press).

Reuters P., (2012). Draining Development? Controlling Flows of Illicit Funds from Developing Countries. The World Bank.

Rusina A., (2020). Name and shame? Evidence from the European Union tax haven blacklist. International Tax and Public Finance Journal.27(1): 1364-1424

Sabbadini T., (2010). "Manufacturing Portfolio Theory". International Institute for Advanced Studies in Systems Research and Cybernetics.

Sahadeth C., (2014).Illicit Financial Flows and Capital Flight in Africa. Briefing Note to the UN Economic Commission for Africa.

Schlenther, B.O. (2016), "Addressing illicit financial flows in Africa: How broad is the whole of government approach supposed to be?", Journal of Financial Crime, 23(4): 1074-1091

Signe L., Sow M., and Madden P., (2020). Illicit financial flows in Africa: Drivers, destinations, and policy options. Africa Growth Initiative, Brookings

Slemrod, J. and J. D. Wilson (2006) "Tax Competition with Parasitic Tax Havens" NBER Working Paper 12225

Songailaite M., (2020). Differences, Similarities, and Proposals for the OECD and the EU Blacklisting Measures. Masters' Thesis. Uppsala University, Sweden

Somorin O.A., (2012). Tejutax Reference Book on the Nigerian Tax System, General Accounting and Taxation Terms. Volumes 1 and 2. Malthouse Publishers, Lagos, Nigeria

UNDP (United Nations Development Programme) (2011) Illicit Financial Flows from the Least Developed Countries: 1990-2008, UNDP Discussion Paper (New York, NY: UNDP).

UNECA (United Nations Economic Commission for Africa) (2013) The State of Governance in Africa: The Dimension of Illicit Financial Flows as a Governance Challenge (Addis Ababa: UNECA).

UNECA. 2015. Report of the High Level Panel on Illicit Financial Flows from Africa. AU/ECA Conference of Ministers of Finance, Planning and Economic Development.

Zucman, G., Fagan, T. L., and Piketty, T. (2016). The Hidden Wealth of Nations: The Scourge of Tax Havens. Chicago: University of Chicago Press 